Research Article

Animal Genetics

\title{
Chromosome comparison among five species of Neotropical cichlids of Cichlasoma and Gymnogeophagus (Perciformes)
}

\author{
Larissa Bettin Pires ${ }^{1}$, Mariana Campaner Usso ${ }^{1}$, Lucia Giuliano-Caetano ${ }^{1}$ and Ana Lúcia Dias ${ }^{1}$ iD \\ ${ }^{1}$ Universidade Estadual de Londrina, Centro de Ciências Biológicas, Departamento de Biologia Geral, \\ Londrina, PR, Brazil.
}

\begin{abstract}
The genera Cichlasoma and Gymnogeophagus belong to the subfamily Cichlinae, the only one in Neotropical cichlids. Cichlasoma dimerus, C. paranaense, C. portalegrense, Gymnogeophagus rhabdotus, and G. lacustris were collected at different points in the Paranapanema and Paraguay basins and the Lagoon of Patos hydrographic system. In addition to conventional analysis, $\mathrm{CMA}_{3}$ fluorochrome staining, and FISH with $18 \mathrm{~S}$ rDNA probe were performed. All species had a diploid number equal to 48 , with inter- and intraspecific differences in karyotype formulae. All species presented a single AgNOR site, except $G$. rhabdotus and the $C$. paranaense population of the Paranapanema River, which revealed more than one pair of nucleolar chromosomes. AgNORs were coincident to 18S rDNA and $\mathrm{CMA}_{3}$. Heterochromatin was distributed in the pericentromeric chromosomal regions and coincident with NORs. For the first time, this work shows cytogenetic data for $C$. portalegrense, G. lacustris, and G. rhabdotus. Although some results reinforce the idea of conservative chromosome evolution of $2 n$ in Cichlinae, interspecific and populational variations observed confirm that chromosomal rearrangements affect the microstructural karyotype diversification in this group of fish.
\end{abstract}

Keywords: Chromosome banding, fish cytogenetics, karyotype diversification, ribosomal DNA.

Received: December 20, 2018; Accepted: April 22, 2019.

\section{Introduction}

Cichlidae represents the largest and most diverse family among Neotropical Perciformes, with about 1700 fish species (Eschmeyer and Fong, 2018). Based on morphological and molecular data, Smith et al. (2008) proposed that all Neotropical cichlids belong to a single subfamily, Cichlinae, as a monophyletic group. This subfamily is subdivided into seven tribes: Astronotini, Chaetobranchini, Cichlasomatini, Cichlini, Geophagini, Heroini, and Retroculini. The genera Cichlasoma and Gymnogeophagus belong to the Cichlasomatini and Geophagini tribes, respectively (Kullander, 2003). Cichlasoma presents a wide distribution, occurring in almost all Neotropical regions, from Mexico to the South of South America (Rican and Kullander, 2006). In contrast, Gymnogeophagus has a more restricted distribution, in which the majority of species is endemic to the coastal river drainage of Uruguay and southern Brazil, in the states of Rio Grande do Sul and Santa Catarina, with exception of G. balzanii, which presents a wider distribution (Reis and Malabarba, 1988).

Send correspondence to Ana Lúcia Dias. Universidade Estadual de Londrina, Centro de Ciências Biológicas, Departamento de Biologia Geral, Rodovia Celso Garcia Cid, PR-445, km 380, 86051-970, Londrina, PR, Brazil. E-mail: anadias@uel.br.
Most of the species of Neotropical cichlids, approximately $60 \%$, present a karyotype with $2 n=48$, but a variation from $2 n=32$ to $2 n=60$ is observed, and chromosomal rearrangements have already been reported in the family (Feldberg et al., 2003; Poletto et al., 2010). Several cytogenetic analyses with the Cichlasomatini tribe show great chromosomal variation in this tribe (Feldberg et al., 2003) in contrast with low ecomorphological diversity, compared with other tribes, such as Geophagini (López-Fernandes et al., 2013), with few chromosomal data (Feldberg and Bertollo, 1984; Pires et al., 2010; Paiz et al., 2017). Hence, these tribes are of interest for cytogenetic studies.

Most cytogenetic studies on Neotropical cichlids are limited to the description of the karyotypic macrostructure (Thompson, 1979; Feldberg and Bertollo, 1985). In recent years, different classes of repetitive DNA have been used to better understand the karyotypic structure of Neotropical cichlids (Gross et al., 2010; Poletto et al., 2010). However, available information is restricted to a small number of species.

This work presents a comparative karyotype analysis of five species of cichlids: Cichlasoma paranaense, $C$. dimerus, C. portalegrense, Gymnogeophagus rhabdotus, and G. lacustris, using techniques of conventional and molecular chromosomal banding, and provides the first cytogenetic information for the last three species. The data 
presented are a contribution to a better understanding of the structure and karyotype evolution in this group of fish.

\section{Materials and Methods}

The species of Cichlasoma and Gymnogeophagus were collected from different localities of the Paranapanema (PR/SP) and Paraguay/MS hydrographic basins and the hydrographic system Lagoon of Patos/RS (Table 1). The specimens were deposited in the Museum of Zoology at the State University of Londrina (MZUEL) under the voucher numbers: 3937 (Cichlasoma paranaense - Taquari), 3479 (C. paranaense - Paranapanema), 13128 (C. dimerus), 4860 (C. portalegrense), 20102 (Gymnogeophagus rhabdotus), and 20103 (G. lacustris). For convenience, different populations of $C$. paranaense were called population A (Taquari) and population B (Paranapanema), as shown in Table 1. The samples were collected with the permission of the Instituto Brasileiro do Meio Ambiente e dos Recursos Naturais Renováveis (IBAMA), protocol number 11399-1. We also obtained permission from the research ethics committee of the State University of Londrina (Animal Use Ethics number: CEUA 5579.2018.72).

Mitotic chromosomes were obtained by direct preparation removing the anterior kidney according to Bertollo et al. (1978) and then stained with 5\% Giemsa in phosphate buffer ( $\mathrm{pH}$ 6.8). The morphology of the chromosomes was determined based on the ratio of arms, as proposed by Levan et al. (1964). For determination of the fundamental number (FN), the meta-submetacentric (m-sm) chromosomes were considered biarmed and the subtelo-acrocentric (st-a) uniarmed.

Silver nitrate staining revealed active nucleolus organizer regions (AgNORs) and was performed according to Howell and Black (1980). The distribution of constitutive heterochromatin was analyzed by Giemsa C-banding after treatments with $0.1 \mathrm{M} \mathrm{HCl}, \mathrm{Ba}(\mathrm{OH})_{2}$, and $2 \mathrm{X} \mathrm{SSC}$ (Sumner, 1972). GC- and AT-rich sites were detected with chromomycin $\mathrm{A}_{3}\left(\mathrm{CMA}_{3}\right)$ and 4',6-diamino-2-phenylindole (DAPI) according to Schweizer (1980). Fluorescence in situ hybridization (FISH) was performed according to the protocol of Pinkel et al. (1986), with modifications according to Gouveia et al. (2013), using an 18S rDNA probe (Hatanaka and Galetti Jr, 2004). Finally, the slides were analyzed on an epifluorescence microscope (Leica DM2000), equipped with a digital camera. Metaphase images were captured using the Leica Application Suite version 3.1.0. (Leica Microsystems).

\section{Results}

All specimens of Cichlasoma and Gymnogeophagus presented a diploid number (2n) equal to 48 ; however, different karyotype formulae were found: $12 \mathrm{~m}$-sm $+36 \mathrm{st}-\mathrm{a}$ and a fundamental number (NF) equal to 60 for Cichlasoma dimerus (Figure 1a), 14m-sm + 34st-a $(\mathrm{NF}=62)$ for $C$. portalegrense and population $\mathrm{A}$ of $C$. paranaense (Figures $1 \mathrm{~b}$ and $1 \mathrm{c}$, respectively) and $4 \mathrm{~m}-\mathrm{sm}+44 \mathrm{st}-\mathrm{a}(\mathrm{NF}=52)$ for the population $\mathrm{B}$ of $C$. paranaense (Figure 1d). Gymnogeophagus rhabdotus showed 6m-sm + 42st-a (NF $=54)$, and G. lacustris $8 \mathrm{~m}-\mathrm{sm}+40 \mathrm{st}-\mathrm{a}(\mathrm{NF}=56)$ (Figures $2 \mathrm{a}$ and $2 \mathrm{~b}$, respectively). In the latter, an interstitial secondary constriction was identified in the short arm of the largest chromosomal pair, with small heteromorphism (Figure $2 b$, Table 2). No differences were observed between the karyotypes of males and females.

AgNORs were located on a pair of chromosomes for all species, except for the population $\mathrm{B}$ of $C$. paranaense and G. rhabdotus, which showed three to four chromosomes bearing these regions (Figures 1 and 2, boxes). In the population $\mathrm{B}$ of $C$. paranaense, it was possible to observe a variation of two to three AgNORs in the terminal regions of the short arm of a submetacentric pair (pair 1) and the long arm of a subtelo-acrocentric chromosome (chromosome 11) (Figure 1d, box). In Gymnogeophagus rhabdotus, the AgNORs were located on st-a chromosomes: long arm of pair 5 and short arm of pair 12 (Figure 2a).

The other species of Cichlasoma, including population A of $C$. paranaense, presented terminal AgNOR on the short arm of one pair of meta-submetacentric chromosomes (Figures 1a-c, boxes); in G. lacustris AgNOR was located interstitially on the short arm of the largest metacentric pair

Table 1 - Collection sites and hydrographic basins of Cichlidae specimens analyzed. MS = Mato Grosso do Sul; PR = Paraná; RS = Rio Grande do Sul.

\begin{tabular}{|c|c|c|c|}
\hline Species & Collection sites & Hydrographic basins & Number of individuals \\
\hline C. paranaense & Taquari stream/PR $23^{\circ} 10^{\prime} 45.2^{\prime \prime} \mathrm{S} / 50^{\circ} 56^{\prime} 30.9^{\prime \prime} \mathrm{W}$ & Paranapanema River-PR & $4 \mathrm{M}, 2 \mathrm{~F}$ \\
\hline C. paranaense & Paranapanema river/SP $22^{\circ} 42^{\prime} 30.3^{\prime}{ }^{\prime} \mathrm{S} / 1^{\circ} 04^{\prime} 08.4^{\prime}{ }^{\prime} \mathrm{W}$ & Paranapanema River-PR & $2 \mathrm{M}, 2 \mathrm{~F}$ \\
\hline C. dimerus & Miranda river-MS $19^{\circ} 31^{\prime} 24.96^{\prime \prime} \mathrm{S} / 57^{\circ} 02^{\prime} 25.51^{\prime \prime} \mathrm{W}$ & Paraguai River-MS & $4 \mathrm{M}, 6 \mathrm{~F}$ \\
\hline C. portalegrense & $\begin{array}{l}\text { Estação Experimental Agronômica da UFRGS } \\
\left(30^{\circ} 5^{\prime} 38.38^{\prime \prime} \mathrm{S} 51^{\circ} 40^{\prime} 22.4^{\prime \prime} \mathrm{W}\right)\end{array}$ & Laguna dos Patos/RS & $5 \mathrm{M}, 3 \mathrm{~F}$ \\
\hline Gymnogeophagus rhabdotus & $\begin{array}{l}\text { Estação Experimental Agronômica da UFRGS } \\
\left(30^{\circ} 5 \text { '38.38''S } 51^{\circ} 40^{\prime} 22.4^{\prime \prime} \mathrm{W}\right)\end{array}$ & Laguna dos Patos/RS & $3 \mathrm{M}, 3 \mathrm{~F}$ \\
\hline \multirow[t]{2}{*}{ G. lacustres } & Rondinha Lagoon $\left(30^{\circ} 13^{\prime} 53.25^{\prime \prime} \mathrm{S} 50^{\circ} 15^{\prime} 15.17^{\prime}\right.$ 'W) & Laguna dos Patos/RS & $2 \mathrm{M}$ \\
\hline & Total of individuals: 38 & & \\
\hline
\end{tabular}

M: male. F: female. 


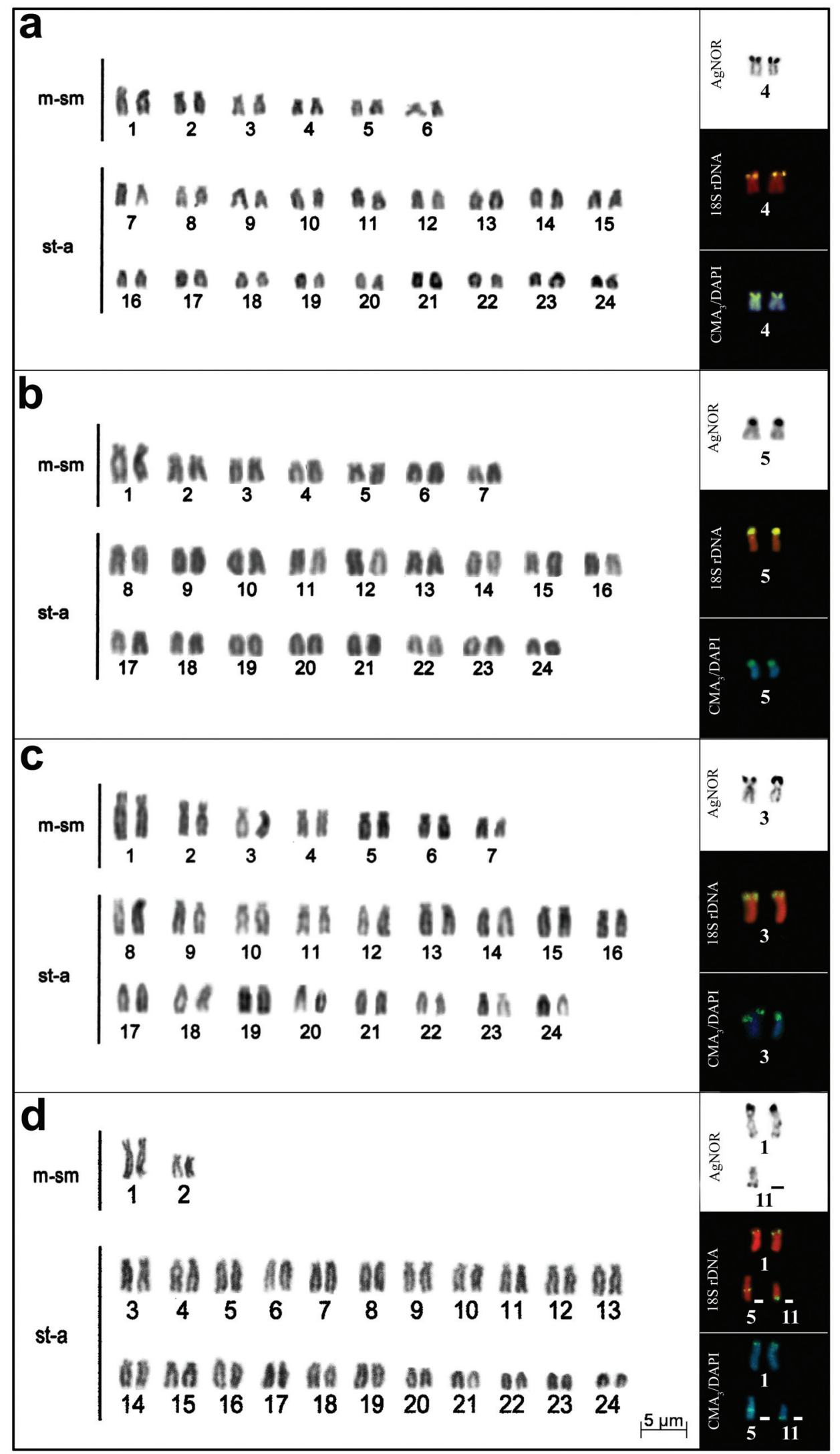

Figure 1 - Karyotype and chromosome pairs with silver nitrate staining, FISH with $18 \mathrm{~S}$ rDNA probe, and $\mathrm{CMA}_{3} / \mathrm{DAPI}$ in Cichlasoma dimerus (a), $C$. portalegrense (b), and C. paranaense, populations A (c) and B (d), respectively. 
Table 2 - Karyotype results for the species of Cichlasoma and Gymnogeophagus analyzed in this study: $2 \mathrm{n}=$ diploid number, $\mathrm{FN}=$ fundamental number, $\mathrm{SC}=$ secondary constriction, $\mathrm{NORs}=$ nucleolar organizer regions; $\mathrm{CMA}_{3}=$ chromomycin $\mathrm{A}_{3}$.

\begin{tabular}{|c|c|c|c|c|c|c|c|}
\hline Species & Locality & $2 n$ & Karyotype formula & $\mathrm{FN}$ & $\mathrm{SC}$ & NORs & $\mathrm{CMA}_{3}$ \\
\hline \multirow[t]{2}{*}{ C. paranaense } & Taquari stream $(\mathrm{PR})$ - population $\mathrm{A}$ & 48 & $14 \mathrm{~m}-\mathrm{sm}+34$ st-a & 58 & - & Single: par $3(t)$ & par $3(\mathrm{t})$ \\
\hline & $\begin{array}{l}\text { Paranapanema river }(\mathrm{SP}) \text { - popula- } \\
\text { tion B }\end{array}$ & 48 & $4 \mathrm{~m}-\mathrm{sm}+44$ st-a & 58 & - & $\begin{array}{l}\text { Multiple: par } 1(\mathrm{t}) \\
\text { crom } 5(\mathrm{i}) \text { e } 11(\mathrm{t})\end{array}$ & $\begin{array}{c}\text { par } 1(\mathrm{t}) \operatorname{crom} 5(\mathrm{i}) \\
\mathrm{e} 11(\mathrm{t})\end{array}$ \\
\hline C. portalegrense & Estação Agronômica da UFRGS (RS) & 48 & $14 \mathrm{~m}+34$ st-a & 62 & - & Single: par $5(\mathrm{t})$ & par $5(\mathrm{t})$ \\
\hline C.dimerus & Miranda river (MS) & 48 & $12 \mathrm{~m}+36 \mathrm{st}-\mathrm{a}$ & 60 & - & Single: par $4(t)$ & $\operatorname{par} 4(\mathrm{t})$ \\
\hline G. rhabdotus & Estação Agronômica da UFRGS (RS) & 48 & $4 \mathrm{~m}+2 \mathrm{sm}+42 \mathrm{st}-\mathrm{a}$ & 54 & - & $\begin{array}{l}\text { Multiple: par } 5(\mathrm{t}) \\
\text { par } 12(\mathrm{t})\end{array}$ & $\operatorname{par} 5(\mathrm{t}) \operatorname{par} 12(\mathrm{t})$ \\
\hline G. lacustris & Rondinha lagoon (RS) & 48 & $4 \mathrm{~m}+4 \mathrm{sm}+40 \mathrm{st}-\mathrm{a}$ & 56 & par 1 (i) & Single: par 1 (i) & par 1 (i) \\
\hline
\end{tabular}

(Figure 2b). Staining with fluorochromes revealed $\mathrm{CMA}_{3}{ }^{+} / \mathrm{DAPI}^{-}$coincident with NORs in all species (Figures 1 and 2).

FISH with $18 \mathrm{~S}$ rDNA probe demonstrated that $C$. dimerus, C. portalegrense, C. paranaense (population A), and $G$. lacustris, present two ribosomal cistrons corresponding to AgNORs (Figures 1a-c, and 2b, boxes). In the other two species, four ribosomal cistrons were observed: in pairs 5 and 12 in the terminal region of G. rhabdotus (Figure 2a, box), and in C. paranaense (population B) in the short arm of pair 1 , in the long arm of chromosomes 5 and 11 , and in interstitial and terminal regions, respectively (Figure 1d, box).
Heterochromatic regions were observed in the pericentromeric regions of the majority of chromosomes and associated with NORs in all species (Figure 3); $C$. paranaense also showed an interstitial marking on the long arm of a subtelo-acrocentric chromosome of pair 5 (Figure $3 \mathrm{~d}$ ) corresponding to NOR, and in G. rhabdotus terminal heterochromatic blocks were observed in some chromosomes (Figure 3e).

\section{Discussion}

Despite conservation in diploid number, variations were found in the karyotype formulae of $C$. dimerus and $C$. paranaense (population $\mathrm{B}$ ) in comparison to previously

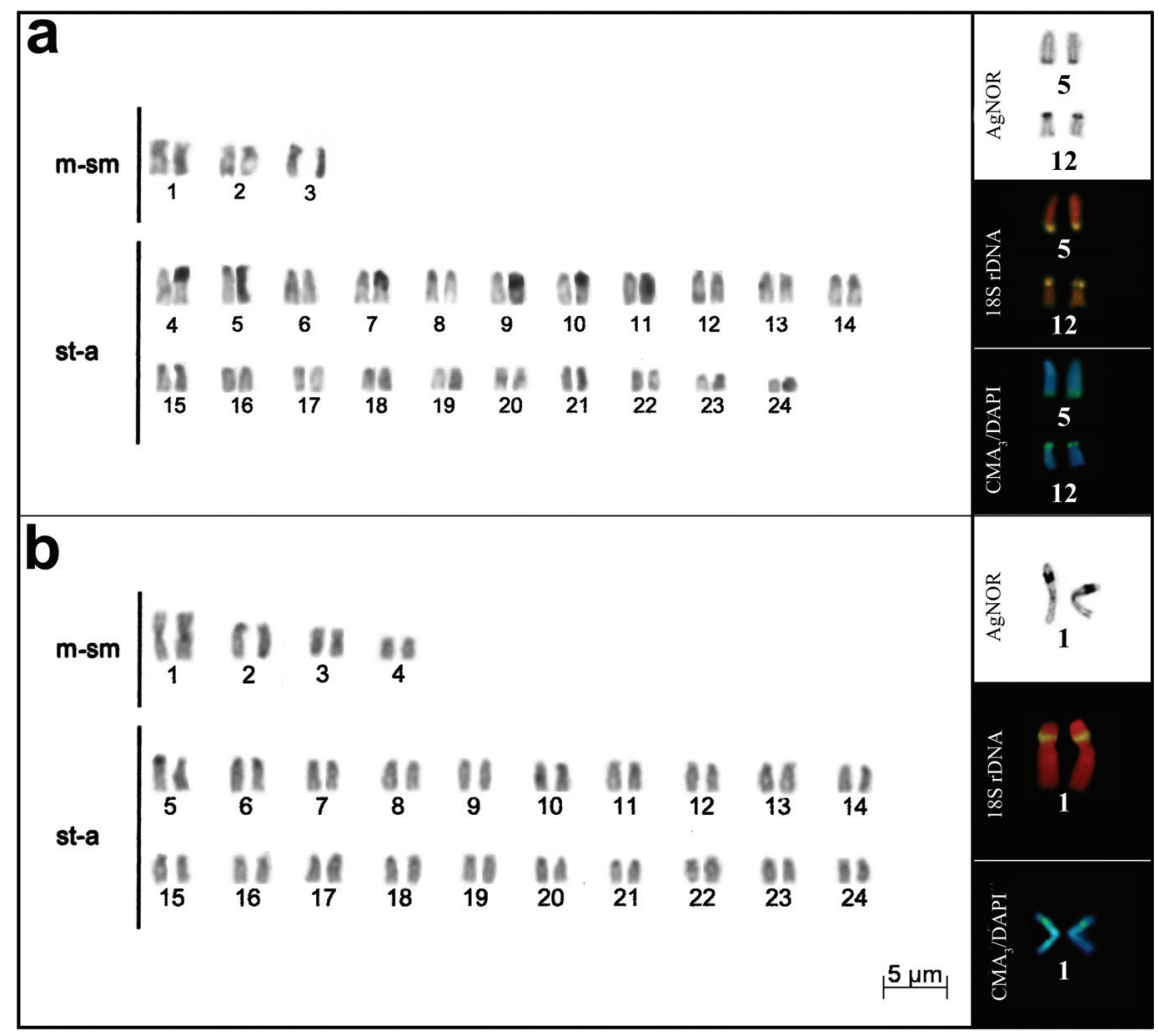

Figure 2 - Karyotype and chromosome pairs with silver nitrate staining, FISH with $18 \mathrm{~S}$ rDNA probe, and $\mathrm{CMA}_{3}$ /DAPI in Gymnogeophagus rhabdotus (a) and G. lacustris (b), respectively. 


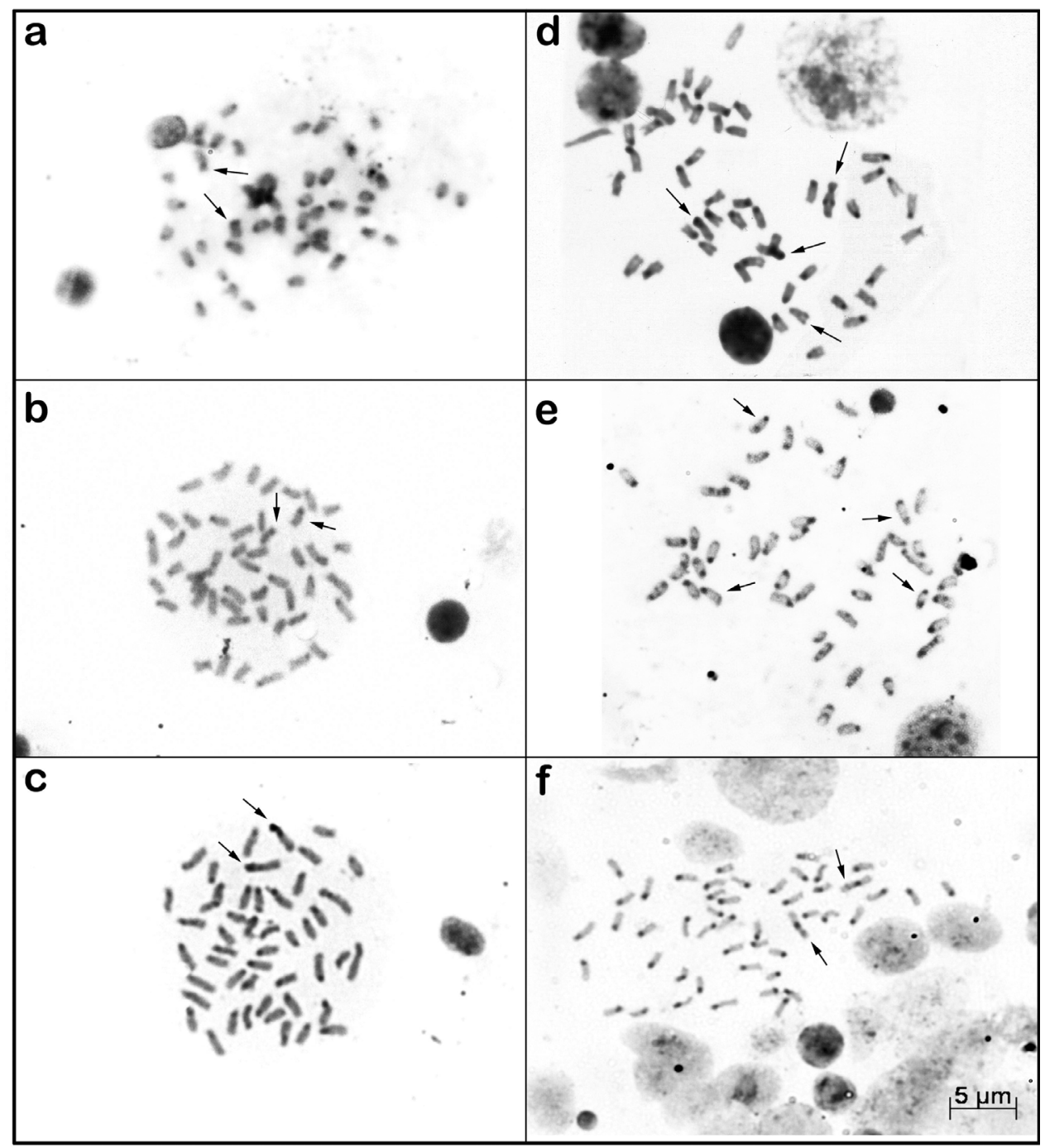

Figure 3 - Somatic metaphases after C banding in Cichlasoma dimerus (a), C. portalegrense (b), C. paranaense, populations A (c) and B (d), Gymnogeophagus rhabdotus (e) and G. lacustris (f), respectively. The arrows indicate the NORs.

studied populations (Martins et al., 1995; Feldberg et al., 2003; Roncati et al., 2007; Poletto et al., 2010). Pericentric inversions seem to be the mechanism that predominantly contributed to these variations, since the diploid number was not altered, as observed by Thompson (1979), Feldberg et al. (2003), and Poletto et al. (2010) in other cichlid species. However, other rearrangement events cannot be ruled out in the family, as in Tilapia mariae, in which chromosomal fusion processes would explain the reduction of 2n to 40 chromosomes (Poletto et al., 2010), and in Symphysodon species, where successive translocation events, fissions, and/or fusions would have contributed to the formation of the most highly derived karyotype in the Cichlidae family $(2 \mathrm{n}=60)$ (Mesquita et al., 2008).

Recent studies show that the centromeres can be repositioned without any chromosomal rearrangement (Rocchi et al., 2012). This phenomenon of centromere repositioning could explain the difference in the karyotype formulae be- tween C. paranaense of the two localities, as also proposed by Schneider et al. (2013) for some species of cichlids.

Except for population B of C. paranaense and $G$. rhabdotus, which presented multiple NORs, all cichlids analyzed in the present study had only one nucleolar chromosomal pair, characterizing a single NOR system and confirming the ancestral condition proposed by Feldberg et al. (2003). However, differences in chromosome types and location of these sites were observed. These results are similar to those found in other species of Cichlasoma and Gymnogeophagus, such as C. facetum (Feldberg and Bertollo, 1985; Vicari et al., 2006), C. paranaense (Martins et al., 1995), and G. labiatus (Pires et al., 2010), presenting only a variation in the identification of the carrier chromosome, or in metacentric (Martins et al., 1995) or subteloacrocentric chromosomes (Vicari et al., 2006), evidencing once again that chromosomal rearrangements are occurring in the group. 
Gymnogeophagus rhabdotus presented two chromosomal pairs bearing ribosomal cistrons, an unusual pattern in the Geophaginae tribe, even though only few species were analyzed. However, there are reports of single NORs in Geophagus brasiliensis, Gymnogeophagus gymnogenys, and Satanoperca acuticeps (Brum et al., 1998; Feldberg et al., 2003; Pires et al., 2010), and multiple NORs only in Gymnogeophagus setequedas (Paiz et al., 2017). In population B of C. paranaense, a chromosomal pair and two non-homologous chromosomes (chromosomes 5 and 11) with ribosomal cistrons were observed; chromosome 5 had an interstitial signal, coincident with the heterochromatin, but not corresponding to AgNOR sites. The occurrence of $18 \mathrm{~S}$ rDNA sites in non-homologous chromosomes and the location of these genes in the long arm are uncommon in $C$. paranaense, and may indicate a particular characteristic of this species and population. According to the literature, most sites are located on the short arm of the chromosomes, and can be of the m-sm group (Poletto et al., 2010; Perazzo et al., 2011), or the st-a group (Vicari et al., 2006; Pires et al., 2008; Gross et al., 2010; Poletto et al., 2010).

In the Geophagini and Cichlasomatini tribes, as in Cichlidae in general, the pattern of single NORs is the most common one (Poletto et al., 2010), indicating that this characteristic can be considered plesiomorphic. Reports of multiple NORs, confirmed by FISH in cichlids, are scarce, and were reported in only seven species, including those described in this study: Mesonauta festivus (Poletto et al., 2010), Symphysodon aequifasciatus $S$. discus and S. haraldi (Gross et al., 2010), and Gymnogeophagus setequedas (Paiz et al., 2017). It is worthy of note that four of these species of the genera Mesonauta and Symphysodon belong to the Heroini tribe, considered as derived within the subfamily Cichlinae. The NORs were $\mathrm{CMA}_{3}$ positive, rich in GC base pairs, as already shown in other species of Geophaginae and Cichlasomatinae by Loureiro et al. (2000), Vicari et al. (2006), and Pires et al. (2010).

The heterochromatin in the species of this study maintains the typical general distribution pattern found in cichlids, in pericentromeric and terminal regions, as observed in different species of Cichlasoma (Martins et al., 1995; Vicari et al., 2006; Roncati et al., 2007) and Gymnogeophagus (Roncati et al., 2007; Pires et al., 2010), except for the population $\mathrm{B}$ of $C$. paranaense, which also presented a chromosome with interstitial marking.

The location of NORs in terminal regions may be the factor that facilitates the transposition of these sequences to other chromosomes through translocation events, as observed by Gross et al. (2010) in some species of Symphysodon, which could explain the origin of the interstitial ribosomal cistron found in only a large subtelo-acrocentric chromosome (chromosome 5). In addition, the association of heterochromatin and ribosomal sites may be related to the variability in location and number of the active NORs, a pattern commonly observed in Neotropical cichlids
(Schneider et al., 2013). Besides that, the differences between the populations may be due to their geographical isolation, so that this could facilitate the fixation of chromosomal rearrangements in the populations (Oliveira et al., 1988), and possibly C. paranaense is a cryptic species.

The karyotype pattern observed in the species of this study reinforces the idea of a conservative diploid number in this group of fish. However, variations in karyotype formulae and location of NORs among the species and populations of $C$. paranaense confirm that chromosomal rearrangements are acting in the diversification of this group of fish.

\section{Acknowledgments}

The authors thank Prof. Dr. Luiz Roberto Malabarba of the Zoology Laboratory at the Universidade Federal do Rio Grande do Sul (UFRGS) for the identification of specimens. This research was supported by Coordenacão de Aperfeiçoamento de Pessoal de Nível Superior (CAPES) Finance Code 001 and Conselho Nacional de Desenvolvimento Científico e Tecnológico $(\mathrm{CNPq})$. The research received permission from the Instituto Brasileiro do Meio Ambiente e dos Recursos Naturais Renováveis (IBAMA) to collect fish specimens.

\section{Conflict of Interest}

The authors have no conflicts of interest to declare.

\section{Author Contribution}

ALD and LBP conceived and designed the study, LGC and LBP collected the samples, LBP perfomed the cytogenetic analysis, LBP and MCU wrote the manuscript and designed the figures, all authors read and approved the final version.

\section{References}

Bertollo LAC, Takahashi CS and Moreira-Filho O (1978) Cytotaxonomic considerations on Hoplias lacerdae (Pisces, Erythrinidae). Braz J Genet 1:103-120.

Brum MJI, Oliveira CC, Voigt N and Côrrea MMO (1998) Karyotypic discrepancy between populations of Geophagus brasiliensis (Perciformes: Cichlidae), including the topotypical population, with possible taxonomic implications. J Comp Biol 3:177-184.

Feldberg E and Bertollo LAC (1984) Discordance in chromosome number among somatic and gonadal tissue cells of Gymnogeophagus balzanii (Pices: Cichlidae). Braz J Genet 4:639645.

Feldberg E and Bertollo LAC (1985) Karyotypes of 10 species of Neotropical cichlids (Pisces, Perciformes). Caryologia 38:257-268.

Feldberg E, Porto JIR and Bertollo LAC (2003) Chromosomal changes and adaptation of cichlid fishes during evolution. In: Val AL and Kapoor BG (eds) Fish adaptations. Science publishers, Enfield, 418 p. 
Gouveia JG, Moraes VPO, Sampaio TR, Rosa R and Dias AL (2013) Considerations on karyotype evolution in the genera Imparfinis Eigenmann and Norris 1900 and Pimelodella Eigenmann and Eigenmann 1888 (Siluriformes: Heptapteridae). Rev Fish Biol Fisheries 23:215-227.

Gross MC, Schneider CH, Valente GT, Martins C and Feldberg E (2010) Variability of 18S rDNA locus among Symphysodon fishes: Chromosomal rearrangements. J Fish Biol 76:11171127.

Hatanaka T and Galetti Jr PM (2004) Mapping of the 18S and 5S ribosomal RNA genes in the fish Prochilodus argenteus Agassiz, 1829 (Characiformes, Prochilodontidae). Genetica 122:239-244.

Howell WM and Black DA (1980) Controlled silver staining of nucleolus organizing regions with a protective colloidal developer: a one step method. Experientia 36:1014-1015.

Kullander SO (2003) Family Cichlidae. In: Reis RE, Kullander SO and Ferraris Jr CJ (eds) Check list of the freshwater fishes of South and Central America. EdiPUCRS, Porto Alegre, p 605.

Levan A, Fredga K and Sandberg AA (1964) Nomenclature for centromeric position on chromosome. Hereditas 52:201204.

López-Fernández H, Arbour JH, Winemiller KO and Honeycutt RL (2013) Testing for ancient adaptive radiations in Neotropical cichlid fishes. Evolution 67:1321-1337.

Loureiro MA, Giuliano-Caetano L and Dias AL (2000) Cytogenetic characterization of two species of the genus Crenicichla (Pisces, Cichlidae). Cytologia 65:57-63.

Martins IC, Portella-Castro ALB and Júlio JRHF (1995) Chromosomes analysis of 5 species of the Cichlidae family (Pisces, Perciformes) from the Parana river. Cytologia 60:223-231.

Mesquita DR, Porto JIR and Feldberg E (2008) Chromosomal variability in the wild ornamental species of Symphysodon (Perciformes: Cichlidae) from Amazon. Neotrop Ichthyol 6:181-190.

Oliveira CLF, Almeida-Toledo LM, Foresti F, Britski HA and Toledo-Filho SA (1988) Chromosome formulae of Neotropical freshwater fishes. Braz J Genet 11:577-624.

Paiz LM, Baumgärtner L, da Graça WJ, Margarido VP and Pavanelli CS (2017) Cytogenetics of Gymnogeophagus setequedas (Cichlidae: Geophaginae), with comments on its geographical distribution. Neotrop Ichthyol 15:e160035.

Perazzo G, Noleto RB, Vicari MR, Machado PC, Gava A and Cestari MM (2011) Chromosomal studies in Crenicichla lepidota and Australoheros facetus (Cichlidae, Perciformes) from extreme southern Brazil. Rev Fish Biol Fisheries 21:509-515.

Pinkel D, Straume T and Gray JW (1986) Cytogenetic analysis using quantitative, high sensitivity fluorescence hybridization. Proc Natl Acad Sci U S A 83:2934-2938.

Pires LB, Giuliano-Caetano L and Dias AL (2008) Karyotype similarities among two populations of Geophagus brasiliensis (Perciformes, Cichlidae) from the Tibagi river basin/PR/Brazil. Caryologia 61:135-138.
Pires LB, Giuliano-Caetano L and Dias AL (2010) Cytogenetic characterization of Geophagus brasiliensis and two species of Gymnogeophagus (Cichlidae: Geophaginae) from Guaíba Lake, RS, Brazil. Folia Biol (Krakow) 58:29-34.

Poletto AB, Ferreira IA, Cabral-de-Mello DC, Nakajima RT, Mazzuchelli J, Ribeiro HB, Venere PC, Nirchio M, Kocher TD and Martins C (2010) Chromosome differentiation patterns during cichlid fish evolution. BMC Genetics 11:50.

Reis RE and Malabarba LR (1988) Revision of the neotropical cichlid genus Gymnogeophagus Ribeiro, 1918, with descriptions of two new species (Pisces, Perciformes). Rev Bras Zool 4:259-305.

Rican O and Kullander SO (2006) Character- and tree-based delimitation of species in the 'Cichlasoma' facetum group (Teleostei, Cichlidae) with the description of a new genus. $\mathrm{J}$ Zool Syst Evol Res 44:136-152.

Rocchi M, Archidiacono N, Schempp W, Capozzi O and Stanyon R (2012) Centromere repositioning in mammals. Heredity 108:59-67.

Roncati HA, Pastori MC and Fenocchio AS (2007) Cytogenetic studies and evolutive considerations on fishes of the amily Cichlidae (Perciformes) from Parana River (Argentina). Cytologia 72:379-384.

Schneider CH, Gross MC, Terencio ML, Artoni RF, Vicari MR, Martins C and Feldberg E (2013) Chromosomal evolution of Neotropical cichlids: The role of repetitive DNA sequences in the organization and structure of karyotype. Rev Fish Biol Fisheries 23:201-214.

Schweizer D (1980) Simultaneous fluorescent staining of R bands and specific heterochromatic regions (DA/DAPI) in human chromosomes. Cytogenet Cell Genet 27:190-193.

Smith WL, Chakrabarty P and Sparks JS (2008) Phylogeny, taxonomy, and evolution of Neotropical cichlids (Teleostei: Cichlidae: Cichlinae). Cladistics 24:625-641.

Sumner AT (1972) A simple technique for demonstrating centromeric heterochromatin. Exp Cell Res 74:304-306.

Thompson KW (1979) Cytotaxonomy of 41 species of Neotropical Cichlidae. Copeia 4:679-691.

Vicari MR, Artoni RF, Moreira-Filho O and Bertollo LAC (2006) Basic and molecular cytogenetics in freshwater Cichlidae (Osteichthyes, Perciformes). Karyotypic conservationism and divergence. Caryologia 59:260-266.

\section{Internet Resources}

Eschmeyer WN and Fong JD (2018) Species by family/subfamily in the catalog of fishes, http://researcharchive.calacademy.org/research/Ichthyology/catalog/SpeciesByFamily.asp (accessed 15 January 2018).

Associate Editor: Yatiyo Yonenaga-Yassuda

License information: This is an open-access article distributed under the terms of the Creative Commons Attribution License (type CC-BY), which permits unrestricted use, distribution and reproduction in any medium, provided the original article is properly cited. 